\title{
正面越流破堤の室内実験による再現性の検討 REPRODUCIBILITY OF SMALL SCALE HYDRAULIC EXPERIMENT ON CROSS-LEVEE BREACH BY OVERFLOW
}

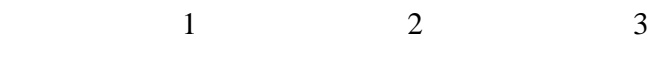 \\ Yasuharu WATANABE, Masato YAMAMOTO, Tomonori SHIMADA \\ 1 正会員工博北見工業大学教授社会環境工学科 ( $\bar{\top} 090-8507$ 北海道北見市公園町 165 番地) \\ 2 学生員 北見工業大学大学院工学研究科土木開発工学専攻 ( $\bar{\top} 090-8507$ 北海道北見市公園町 165 番地) \\ 3 正会員独立行政法人土木研究所 寒地土木研究所 (广 062-8602 札幌市豊平区平岸 1 条 3 丁目)
}

\begin{abstract}
River bank failure causes a heavy disaster. Many experiments had been conducted. Full-scale hydraulic experiment is very few, because of it has a limit to conduct in terms of space and budget. Therefore, many experiments were conducted in small scale and they need to be compared with the actual phenomenon. The large scale hydraulic experiment on river bank failure was conducted at Chiyoda experiment flume in 2008. We conducted small scale experiments on river bank failure and examined the reproducibility of the small scale experiments by comparison with the Chiyoda experiment. Fine-grained soil strongly influences the widening process of bank failure. In order to reproduce the results of experiment at Chiyoda experimental flume on dike failure, it is necessary to remove the fine material from the material of scaled dikes. And it is found that the time scale of widening process of bank failure follows the Froude similarity law.
\end{abstract}

Key Words: Chiyoda, overflow, small scale experiments, similarity rule, burst in the dike

\section{1.はじめに}

日本は欧米諸国と比べると河川の汇濫原に人口, 資産 が集中しており, これは平地の少ない日本の特徵であり, 氾濫原の開発を経て発展してきたことに起因する. 脆弱 な国土構造から人々の生活空間を守るため, 河川堤防は, 既往洪水の規模や頻度に応じて数々の段階的な改修が 行われ現在に至る ${ }^{1)}$. このような築堤の経過から, 河川 堤防は樣々な土質や内部構造をもつ複雑な構造物とな り, 洪水に対する堤防の強度を把握することが困難なた め, 決壤して大災害となる危険性を孕んでいる ${ }^{2)}$.

河川堤防の決壊メカニズムについては水路実験や数 值解析からいくつもの知見が得られている ${ }^{3)}$. しかしな がら, 実物大実験（以下，「実スケール」）の破堤を実験 水路で忠実に再現しているものを取り扱った研究は限 られており,かつ水路実験に用いる堤体材料の違いから， 再現性を検討しているものはほとんどない.

平成 20 年に実スケールの破堤実験が北海道帯広近郊 の千代田実験水路で実施され, 数多くの知見が得られて いる ${ }^{3)}$. 図-1に弚の時に撮影されたものの一部を示し た.これは堤体の越流部を正面やや上方から撮影した もので, 決壞口の広がり (以下, 「拡幅」) を読み取るこ とができる, この実験結果と, 室内水路の破堤実験とを 比較することで, 室内水路スケールでの実験の再現性の 是非を問うことができるようになった. 室内水路におい て,より高い再現性が得られる実験条件を明確にするこ

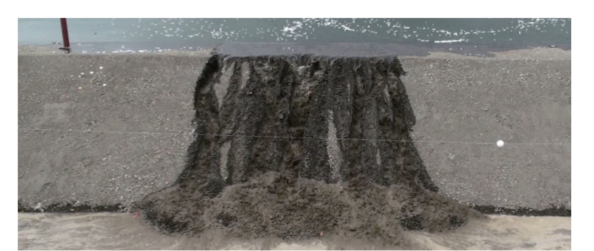

越流開始直後

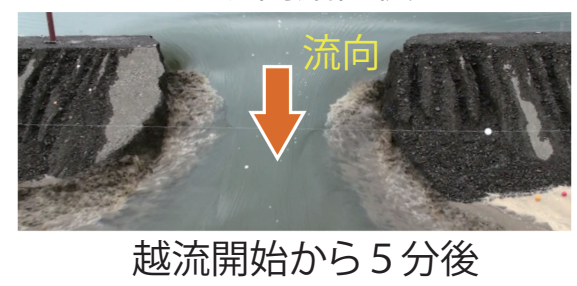

図-1 実スケールの破堤状況 ${ }^{3)}$

とは, 今後樣々な破堤実験を低コストで実施していくに あたって重要であり,千代田実験水路における実験結果 は, 室内破堤実験の罚型として利用することができる.

河川堤防の決壤は局所的に起こり, 決壤口は外水流入 とともに拡幅し, 堤防地盤に洗掘穴を形成することが知 られている ${ }^{2)}$. 水路実験では, 堤防地盤の洗掘穴が実ス ケールより掘れ過ぎるといった現象が生じているが, 原 因は未解明である. 拡幅だけでなく, 洗掘穴の再現と特 性を把握することも重要である.

以上の観点から, まず実スケールと室内実験の現象の 違いを把握し, 弚の原因と再現性を堤体材料の観点から 明らかにし, 考察を加えることとした. 


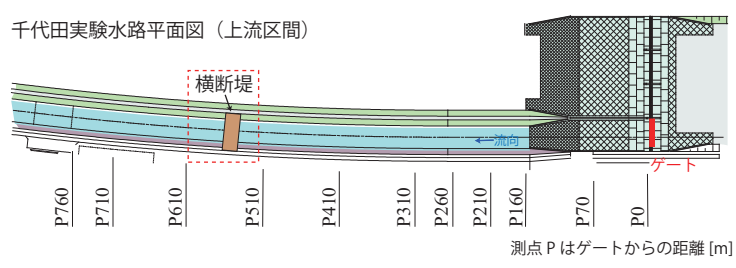

図-2 千代田実験水路概要

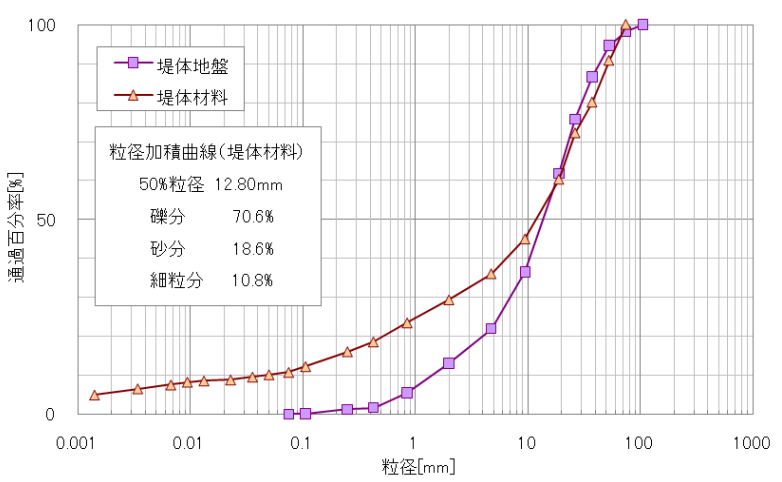

図-3 千代田実験水路の粒度分布

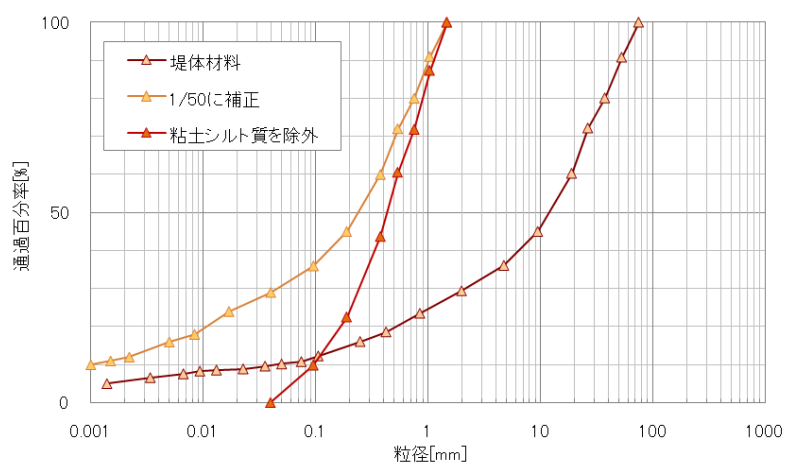

図-4 実スケールの粒度分布を室内スケールに相似

\section{2. 実験水路の概要}

(1) 千代田実験水路の概要

平成 20 年 8 月 15 日に千代田実験水路で横断堤破堤 実験が実施された. 越水破堤に関する研究の発展を目的 として行われ, 実スケールにおける正面越流破堤メカ二 ズム (破堤のきっかけ・拡幅の過程・洗掘穴の形成過程 など）の時系列での把握が行われた ${ }^{4)}$. 図-2 に水路の概 要を示す. 河床勾配 $1 / 500$, 供給流量は $4 \mathrm{~m}^{3} / \mathrm{s}$, 越水時の 貯留量は $38,000 \mathrm{~m}^{3}$ であり, 高さ $2.5 \mathrm{~m}$, 天端幅 $2 \mathrm{~m}$, 法勾 配 2 割の横断堤を水路全幅 (下幅 $30 \mathrm{~m}$ 、上幅 $40 \mathrm{~m}$ ) に おいて造成している。また破堤のきっかけとなる切欠 は天端中央部に幅 $5 \mathrm{~m}$, 深さ $0.05 \mathrm{~m}$ となっている. 堤体 材料と河床材料は概ね同じ土質からなっており, 粒度分 布を図-3に示す.

\section{(2) 室内実験水路の概要}

千代田実験水路で行われた実スケールの実験を室内規 模で再現するにあたって, 縮尺を $1 / 50$ と設定した. 概要 を図-5 に示す. 河床勾配 $1 / 500$ 、供給流量は $210 \mathrm{~cm}^{3} / \mathrm{s}$ 、 越水時の貯留量は $0.3038 \mathrm{~m}^{3}$ とした. フルードの相似則

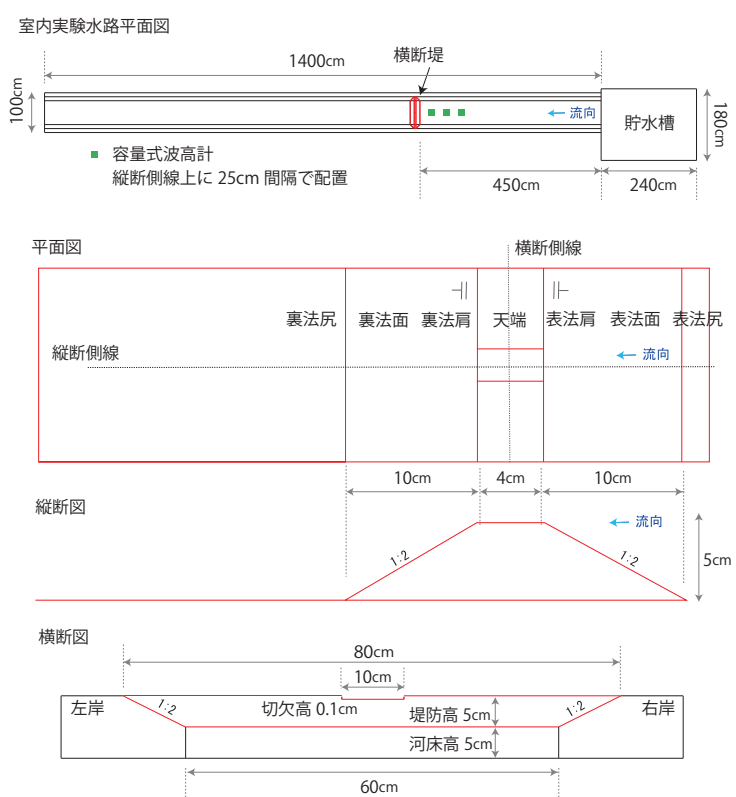

図-5 室内実験水路概要

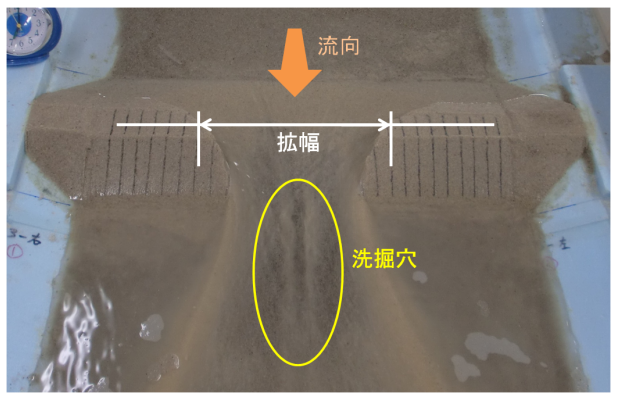

図-6 室内実験の状況

を用い,河床材料には基本的に縮尺 $1 / 50$ で東北硅砂 4 号 を使用した. 堤体材料も同じく東北硅砂を用い, 4 号から 9 号までの混合砂から堤体を造成している. 硅砂は扱い が容易であり, 実験の簡易化を目的として使用している. また, 実スケールの土質を, 室内スケールに置き換えた 粒度分布を図-4に示した. 実スケールの土質を, 室内ス ケールに置き換えた場合, 粘土シルト質の土が占める割 合が大きくなり, 再現性に影響が出る恐れがある. 弚こ で粘土シルト質を除外した粒径加積曲線を描きこれを 目安として硅砂の配合比を決定した. 堤体は硅砂の混合 砂に水を加えて締め固め造成する. 千代田実験水路にお ける堤体の自然含水比は, 試料を採取した地点によって, 礫分を多く含むものと, 砂分を多く含むものとで異なっ

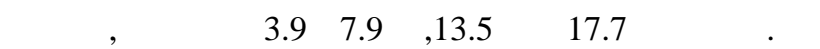
た締め固め度は $92.8 \%$ である ${ }^{5}$. 室内実験水路におけ る含水比, 締め固め度の算定は,JIS-A-1210 の土の突き 固めによる締め固め試験より,樣々な混合砂で試験を行 い, 結果として最適含水比は $12 \%$ 13\%の間に存在し, 堤体造成時の締め固め度は,いずれも $90 \%$ 程であった. 堤体の造成時は, 堤体材料中の水分か蒸発することも考 え, 全ての実験ケースで含水比を最適含水比の最大值で ある $13 \%$ と設定し, 実験時はおおむね最適含水比にな 
表-1 硅砂の配合比

\begin{tabular}{|c||c|c|c|c|c|c|}
\hline 実験番号 & 4 号 & 5 号 & 6 号 & 7 号 & 8 号 & 9 号 \\
\hline \hline $\mathrm{A}-1$ & 2 & 0 & 2 & 0 & 1 & 0 \\
\hline $\mathrm{A}-2$ & 4 & 3 & 3 & 1 & 1 & 1 \\
\hline $\mathrm{A}-3$ & 1 & 1 & 0 & 0 & 0 & 0 \\
\hline $\mathrm{A}-4$ & 0 & 1 & 1 & 0 & 0 & 0 \\
\hline $\mathrm{A}-5$ & 0 & 0 & 1 & 1 & 0 & 0 \\
\hline
\end{tabular}

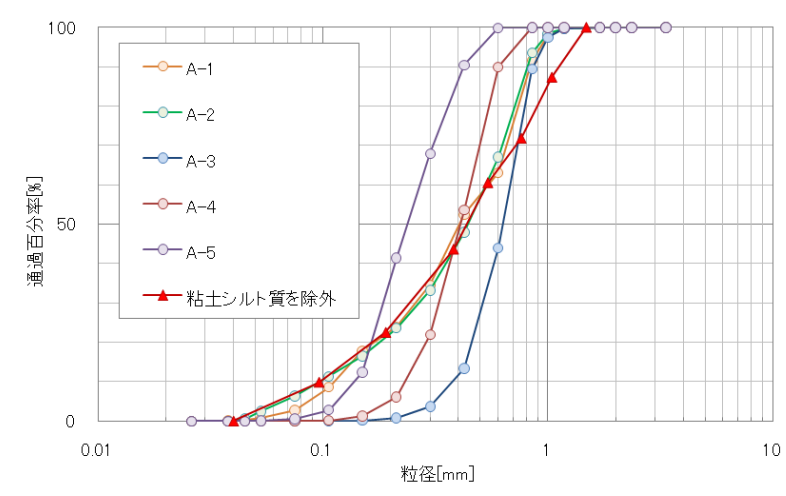

図-7 実スケールの粒度分布を室内スケールに適応

るように配慮した. 実スケールと室内実験の含水比は, 両者の土が持っている物性によって異なるため, 締め固 め度を 90 \%程で統一させることとした. 堤体の造成後, 図-6に示すように, 拡幅を読み取るために $2 \mathrm{~cm}$ 間隔で メッシュを引いた.

\section{3. 実験条件}

(1) 測定項目

越流量, 破堤幅の拡幅を時系列で把握する必要がある. 越流量については, 堤体より上流側の水位を図-5に示 す位置に設置した容量式波高計 3 台を用いて計測し, 式 (1)より推定した.

$$
Q_{\text {out }}=Q_{\text {in }}+A \frac{\Delta h}{\Delta t}
$$

ここで, $Q_{\text {out }}:$ 横断堤からの越流量, $Q_{i n}:$ 供給流量, $A:$ 堤体上 流側の水路表面積, $\Delta h$ :減少した水位, $\Delta t$ :計測時間刻みで ある. 破堤幅の拡幅は, 図-6で示した拡幅の長さを上方 から撮影した動画から 1 秒間隔で読み取り, 破堤幅の 時間变化とした. また, 実験終了時の形状を走行台車式 砂面計測機を用いて, 洗掘穴の深さや長さを含めて計測 した.

\section{(2) 実験分類}

実験条件は表-1 に一括表示したとおりである.また， 各ケースで用いた粒径加積曲線を図-7に示す. 図-7 は, 図-3の $x$ 軸の範囲を $0.01 \sim 10 \mathrm{~mm}$ に変更して示してい る. また「粘土シルト質を除外」とあるのは粘土シルト 質の物理的特性を除外するため, 千代田実験水路の実験 で用いられた堤体材料のうち, $0.075 \mathrm{~mm}$ 以下の成分を除 外したものの粒径加積曲線であり, 硅砂配合比を決定す

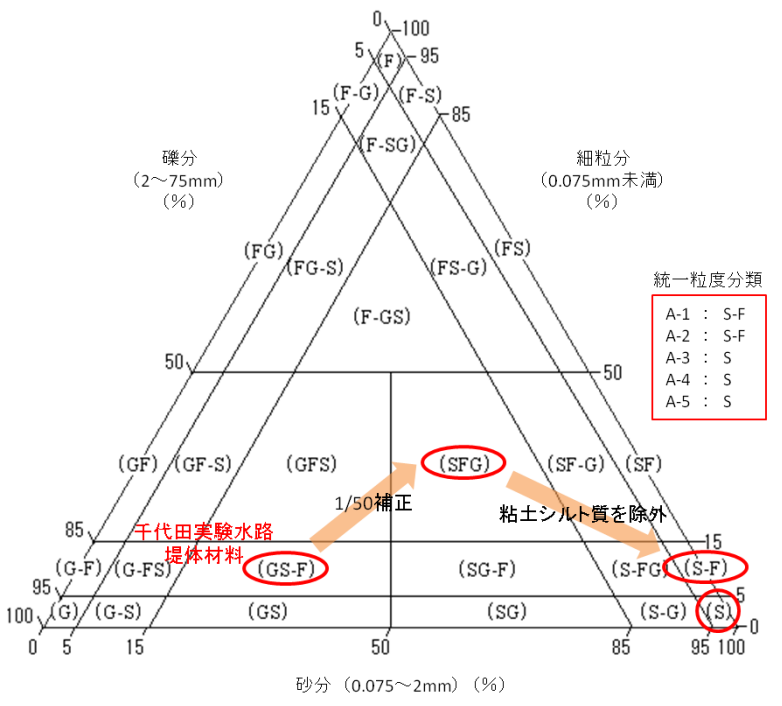

図-8 粗粒度の小分類および細粒度の細分類三角座標

るための目安として用いている. A-1 及び 2 は,「粘土 シル卜質を除外」に添うように配合比を決定した. A-3 は, 「粘土シルト質を除外」の 70 \%粒径と等しくなるよ うに決定した. 同じように,A-4 は 50 \% 粒径,A-5 は 20 \%粒径と等しくなるように決定した. なお,A-3,4,5 は, 粒 径の違いによる現象の違いが明確にでるよう均等係数 を大きくしている.

図-8に, 各ケースの統一粒度分類を示した. また, 千代 田実験水路の堤体材料から, 硅砂配合比の決定までの推 移を三角座標に示した. 実スケールの土質 (GS-F) を, 室内スケールに置き換えた場合, 粒度分類が (SFG) と なる.さらに粘土シルト質を除外すると, (S-F)，(S) となる. 弚れ光れの土質は独自の物性を持っており, 本 来であれば,これら物性を詳しく吟味すべきであるが, 越水中に堤体の含水比等が大きく変化することなど非 常に複雑な現象を扱うことから,ここでは粒径の違いの みに着目して検討を進めることとした.

(3) 実験の流れ

破堤を再現することができる硅砂の配合比を特定す るためにAシリーズとして 5 ケースの実験を行った. ま た、現象の把握と考察を深めるにあたって, A シリーズ の実験結果に応じて, 各種追加実験を行った.

a) 追加実験 1

貯留量と拡幅との関係を明確にするべく, 貯留量が実 スケールより少ない場合の実験.

b) 追加実験 2

洗掘深に実スケールの実験結果との違いか現れるケー スについて, 河床材料か硅砂 4 号のみの場合と違い, よ り実スケールに近い条件である, 堤体材料と河床材料を 同じ配合比とした実験.

c) 追加実験 3

各種解析の結果から再現性が確認できたケースにつ いて, 再実験. 
a）細砂を含まない破堤の経過と特徵・拡幅計測位置 オーバーハングしていない場合（ケースA $-3, \mathrm{~A}-4)$

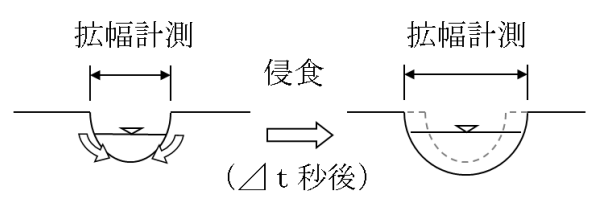

b）細砂袁含破堤の経過と特徽・拡幅計測位置 オーバーハングしている場合（ケースA $-1, \mathrm{~A}-2, \mathrm{~A}-5$ )

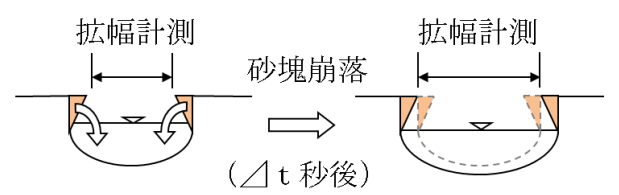

図-9 横断側線における破堤の経過と特徵, 及び拡幅計測位置

\section{4. 実験結果}

\section{(1) 破堤の特徵}

各ケースにおいて破堤状況を観察した結果, 細砂を含 まない場合と含む場合で大きく異なることが判明した. 図-9に光れ光れの破堤の経過と特徵, 及び拡幅計測位置 を示す.ここで細砂とは, 硅砂 7 号〜9 号のことである. このため,ここでは細砂を含まない場合と含む場合とに 分けて記述する.

a) 細砂を含まない破堤の経過 ( ケース A-3,A-4)

実験開始に伴って, 貯留水によって堤体と河床に浸潤 が生じる. 堤内地盤に漏水が発生した場合, 堤体下部が 僅かに法崩れを起こすが, 堤体の破壊には無関係である. 流入水が切欠部を乗り越え, 裏法肩に到達すると, 裏法 斜面に澪筋を形成しながら下刻する. 澪筋が裏法尻に到 達すると, 天端切欠部の洗掘が始まり, さらに洗掘の前 端が表法肩に到達すると, 表法面に扇状の丘を形成しな がら洗掘が続く. 一方で, 拡幅は天端切欠部の洗掘が始 まると同時に拡大していったが, 砂塊として崩壊するこ とは少なく, 砂粒として侵食を受け小規模な崩落によっ て拡大していった. 拡幅は約 2 分間継続し, 兴の後平衡 状態となる.

\section{b) 細砂を含む破堤の経過（ケース A-1,A-2,A-5）}

細砂を含む堤体の場合, 流入水が切欠部を乗り越え, 澪筋を形成し天端切欠部の洗掘が始まるまでの流れは, 前項で述べた経過と同じである. しかし細粒のため, 天 端中央部から形成されたばかりの澪筋にかけて, 細砂が 容易に流送されていた. 拡幅は $5 \mathrm{~cm}$ 程度まで広がると, 切欠部側壁は見かけの粘着力が高く容易には崩落しな いため, 下刻のみが著しく進行する. 切欠部の下刻が進 み, 決壊口となるが, 決壊口側壁が「八の字」のような オーバーハングする形となる. オーバーハングしている 部分が自重に耐えきれなくなると, 砂塊として崩落する. このような崩落を断続的に繰り返しながら拡幅が拡大 し, 約 2 分間継続した後平衡状態となる.
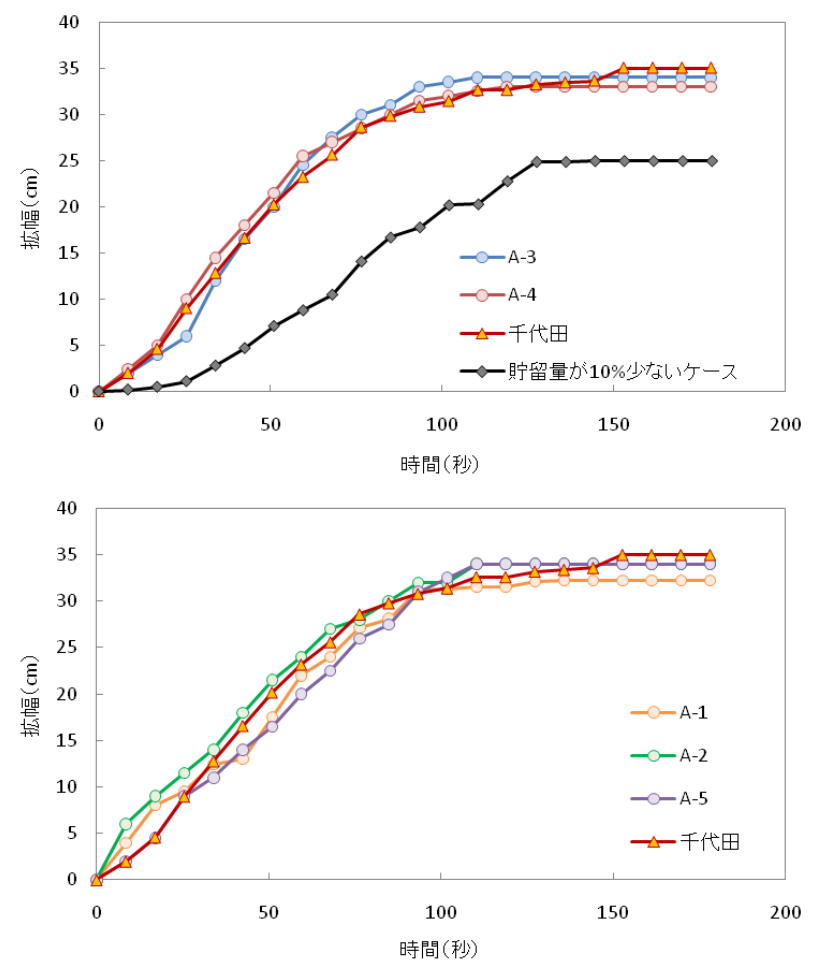

図-10 拡幅の時間的変化

(2) 拡幅の時間的変化

実スケールと室内実験の比較を拡幅の時間的変化で 行う場合, 相似則を用いて時間の縮尺を調整する必要が ある. 破堤は, 重力が卓越する流れであるため, フルード の相似則に従うものとすると,

$$
t_{r}=L_{r}{ }^{1 / 2}=1 / 7.071
$$

ここで, $t_{r}$ :時間縮尺, $L_{r}$ :幾何縮尺 $(1 / 50)$ である.

破堤の特徵の違いを踏まえ, 堤体に細砂を含む場合と 含まない場合の結果を図-10に分けて示した。「千代田」 の表示は, 実スケールの実験結果を室内スケールに置き 換えたものである. いずれの実験も, 拡幅の最終形状は 千代田実験水路による結果と同程度の $35 \mathrm{~cm}$ 付近まで 拡大しているのか読み取れる. 拡幅過程は,A-3,A-4 が最 も実スケールと近い結果となったが, 細砂を含む堤体の 拡幅過程は, 初期段階における拡幅の拡大が実スケール よりやや早いといった開きが見られる.

次に追加実験 1 として, 貯留量と拡幅との関係を見る こととする. 貯留量が A シリーズよりおよ光 10 \%少な い場合 (貯留量を $0.3038 \mathrm{~m}^{3}$ から $0.2677 \mathrm{~m}^{3}$ に変更) の 実験結果を述べる. 図-10の上側のグラフに貯留量が 10 \%少ないケースの 1 例をプロットした.この実験にお いても, 樣々な硅砂の配合比からなる堤体で実験を行っ たが, 拡幅の最終形状はいずれも $25 \mathrm{~cm}$ 程度であり,A シ リーズより $10 \mathrm{~cm}$ 程度少ない結果となった。

拡幅の最終形状は, 硅砂の配合比の違いによっては左 右されず, 貯留量によって支配されているようである. 

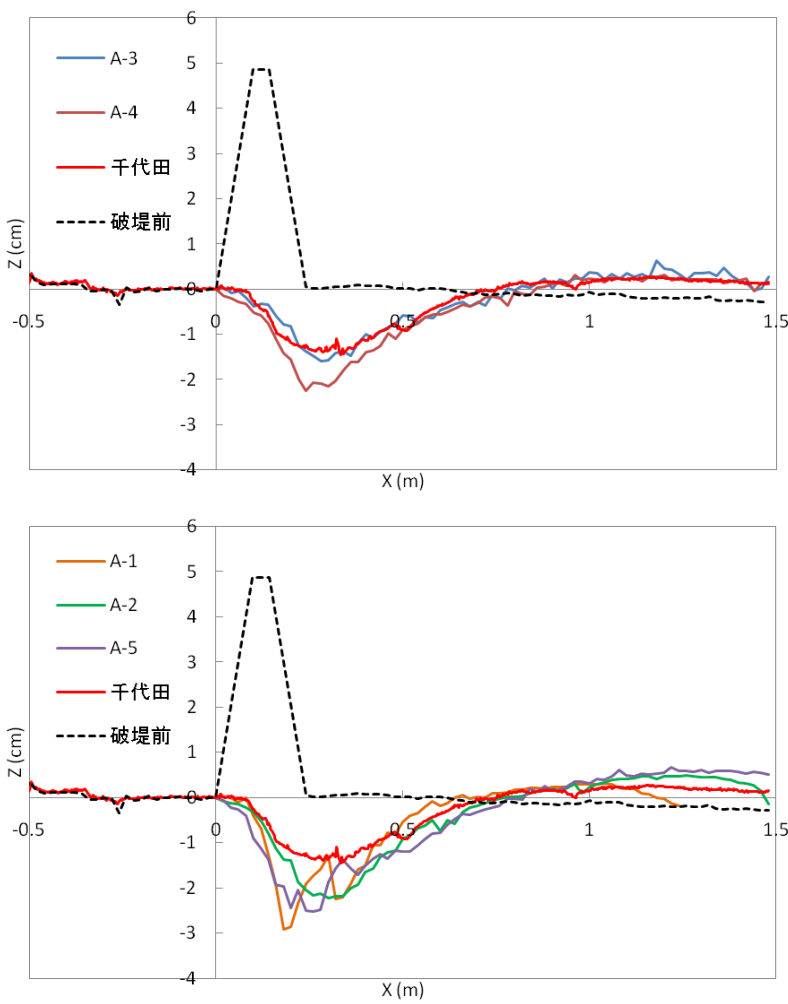

図-11 洗掘穴の形状・縦断側線

(3) 洗掘穴の形状

a) 洗掘穴の比較

前節と同樣に, 破堤の特徵の違いを踏まえ, 堤体に細 砂を含む場合と含まない場合の洗掘穴の形状を分けて

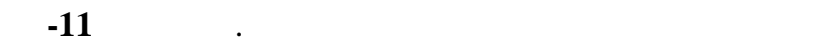
ルと比較するために, 室内スケールで統一している. 流 向は, $x$ 軸に正の方向である. 図-5 の縦断側線を, 表法尻 $(x=0 \mathrm{~m})$ から $1.48 \mathrm{~m}$ まで $2 \mathrm{~cm}$ 刻みて計測した. 千代田 の最大洗掘深か計測された位置は, 縦断側線から左岸側 に $1.5 \mathrm{~m}$ 移動した側線上であったため, 乥れを採用して いる. A-3 を除いて, 堤防地盤の洗掘穴が実スケールよ り掘れ過ぎるといった現象が生じている. とくに, 細砂 を含む堤体で洗掘穴が大きく現れる傾向にある.

b) 河床材料と洗掘穴の関係

洗掘穴の形成が河床材料粒径によって支配されてい る可能性があったため, 追加実験 2 として, 洗掘深に実 スケールとの違いか現れるケースについて, 河床材料が 硅砂 4 号のみの場合と違い, より実スケールに近い条件 である, 堤体材料と河床材料を同じ配合比とした実験を 行った. 河床材料の交換か困難なため, 細砂を含むケー スの A-1 と細砂を含まないケースの A-4 を光れぞれ 1 ケース抽出し,A-1',A-4' とした.

図-12 に洗掘穴の部分における縦断図を示す. 河床材 料と堤体材料を同じにした場合においても, 洗掘穴の掘 れ過ぎが生じ, 洗掘深を再現することはできないことが 分かった. ただし, 河床材料に細砂が含まれた場合, 越 流水によって細砂の移動か容易になされ, 最大洗掘深の 増加や位置が後退するといった変化が見られ, より再現
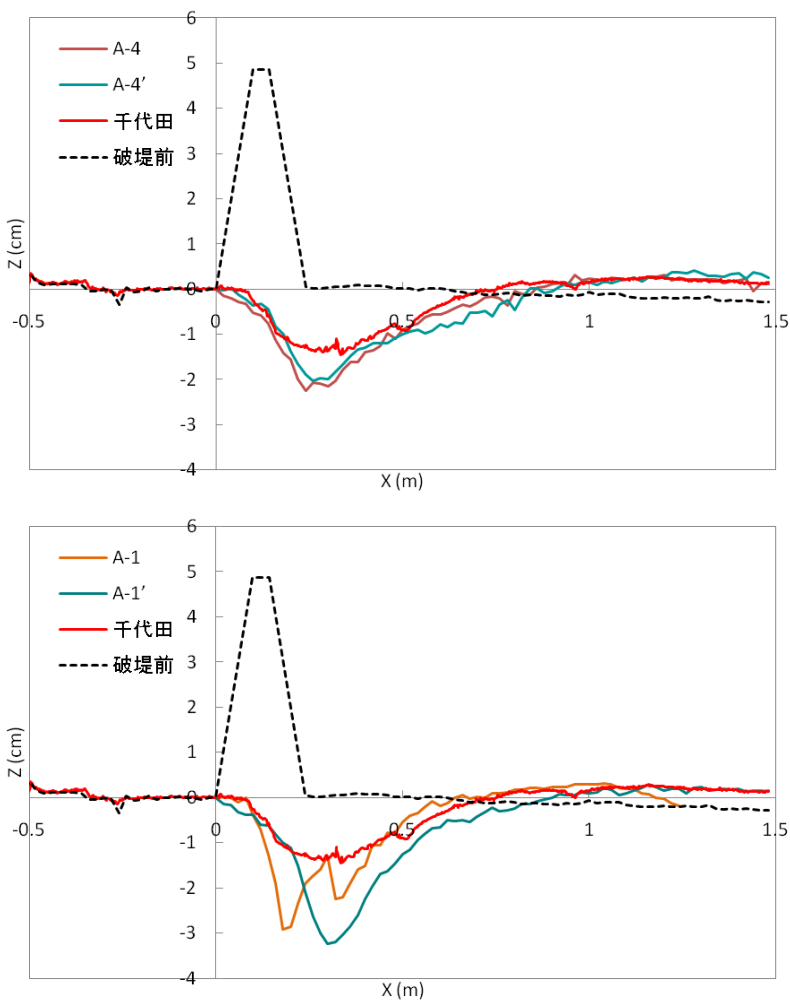

図-12 堤体材料と河床材料が同じ場合の洗掘穴の形状

性が悪くなる結果となった. この原因は, 今後の課題で ある.

\section{(4) 再現性の確認}

以上の結果から, 河床材料は硅砂 4 号のみを使用し, 堤体材料に硅砂 4 号と 5 号を $1: 1$ の割合で配合した条 件の,A-3 が最も実スケールを再現していることが確認 された.なお, 同一の条件で追加実験 3 として, 再現実験 を行ったが, 同じ結果を得た。

\section{5. 考察}

ここまで, 拡幅過程, 拡幅の最終形状, 洗掘穴の形状に おいて実スケールの実験と比較を行い, また細砂を含む 場合, 含まない場合での実験結果の違いを述べた. 拡幅 の最終形状と洗掘穴の形状は, 両者とも実験が終わった 段階の, 形状の再現性を確かめるものであり, 時系列で 逐次変化する現象の再現性を述べることはできない. こ の現象の再現性こ关が, 破堤災害における避難警報等の 対策立案には最も重要である. 拡幅過程は, 時間的変化 を捉えているため, 現象の再現性を確かめる手段として 用いられてきたが, 本実験においても, 図-10に示した, 細砂の有無で比較した拡幅過程のグラフからは, 一見, 細砂の有無に関係なく再現性があるといえるが, 細部で 異なる部分が存在する. ここで, 拡幅過程と同じ, 時系列 データである越流量に注目し, 実スケールの実験結果に おける拡幅過程と越流量の関係性を把握するために, 縦 軸に拡幅過程, 横軸に越流量を与え, 時系列を統一した ものを Q-B 曲線として図-13 に示した。 


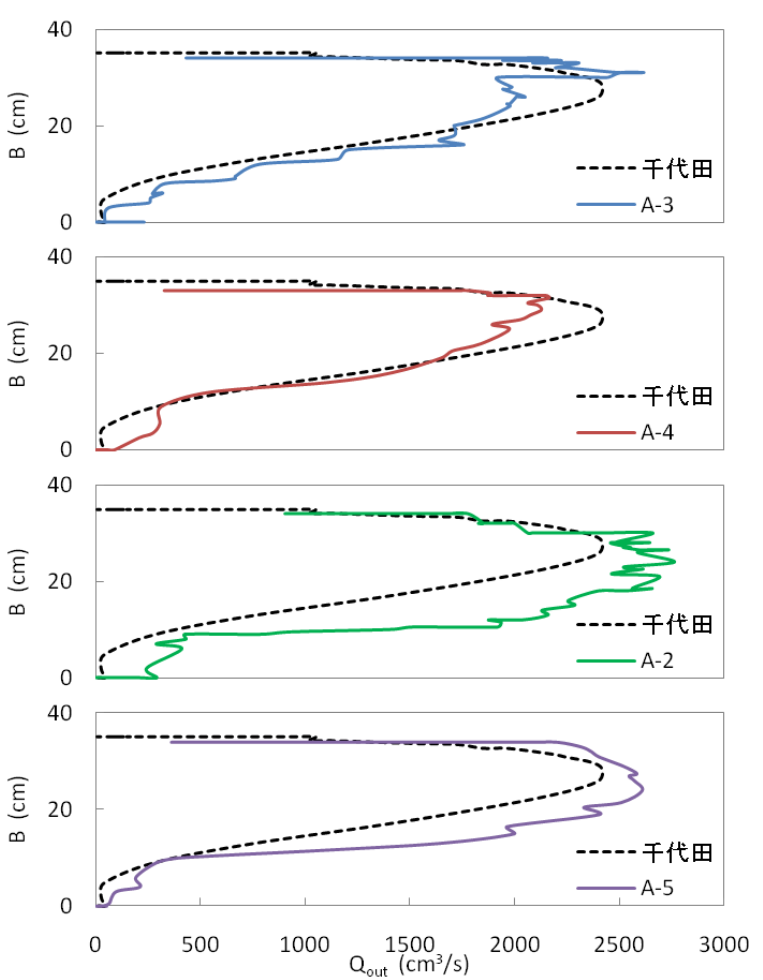

図-13 越流量と拡幅の時間的変化 (Q-B 曲線)

同図は A-2,A-3,A-4 および A-5 を比較するために 4 つのグラフを一括表示しており, 上 2 つのグラフか細砂 を含まない場合のケース A-3 および A-4, 下 2 つのグラ フか細砂を含む場合のケース A-2 および A-5 である. 点 線にて実スケールの実験における拡幅と越流量の変化 を表しているが, 今回の実験と実スケールの実験結果と はほぼ同一の値を示している. すなわち, 越流量の増加 に応じて拡幅が拡大し, 貯留量の減少に伴って, 越流量 がピークを向かえ, 緩やかな弧を描きながら減少し, 平 衡状態となることが読み取れる. なお, すべてのケース において, 初期段階に越流量が卓越しているが, これは 谷の他のケースでも, 同じような越流量の卓越が生じて いることから, 室内実験特有の現象であると思われる. 越流水が切欠部を乗り越え, 澪筋を形成し, 下刻が発達 する速度が実スケールより速いためにここの樣な卓越が 生じるものと思われる. 細砂を含まない A-3,A-4 の 2 ケースと, 実スケールの実験の Q-B 曲線を比較すると, 拡幅が切欠幅程度まで拡大すると, 実スケールの曲線に 沿うような形て現象が進行している. しかし A-4につい ては, 越流量のピークが実スケールよりやや少ない傾向 にある. これは, 拡幅測壁の侵食による土砂供給によっ て洗掘穴が埋没し、越流量が通過する断面が小さくな るためだと考えられる. 次に, 細砂を含む A-2,A-5 の 2 ケースと, 実スケールの Q-B 曲線を比較する. 初期段階 に越流量が卓越し, 拡幅が切欠幅程度まで拡大すると, 切欠部側壁が安定化し, 越流量が急激に増加しているの が読み取れる. 切欠部側壁からの土砂供給がなくなり,
下刻のみが著しく進行している現象を表している．ま た, 図-11 から落ち掘れが実スケールの実験結果より深 いため, 天端開口幅は同じでも深さ方向に大きくなっ ている.よって, 越流量が通過する断面が大きいため, 越 流量のピークは実スケールより大きくなる傾向にある と考えられる. 越流量は, 洗掘穴の形状により左右され る可能性がある.

\section{6. おわりに}

千代田実験水路における正面越流破堤の実験を, 縮尺 を $1 / 50$ と設定した室内実験において再現する場合, 最 終的な形状と現象の両方で再現が確認されたケースは, 河床材料は硅砂 4 号のみを使用し, 堤体材料に硅砂 4 号 と 5 号を $1: 1$ の割合で配合した条件の,A-3 が最も再現 性があると確認できた.

Q-B 曲線を比較することで, 室内実験特有の現象と思 われる下刻が発達する速度の違い, 切欠幅の影響, 切欠 部側壁の安定化がもたらす洗掘穴の掘れ過ぎなど, 拡幅 過程だけでは判断できない現象についても把握するこ とができる.

この Q-B 曲線による検討は今後, 拡幅過程との関係 だけにとどまらず, 越流部の勾配の時間的変化や, 堤体 の粘着力と密接に結び付けることで,より再現性の検討 を深めることができると思われる.

\section{参考文献}

1) 吉川勝秀 : 河川堤防学, 山海堂, pp.65, 2007.

2）藤田裕一郎・田村多佳志・松本嘉雄 : 河川堤防決壊口の拡 大過程に関する実験的研究, 京都大学防災研究所年報, 第 27 号 B-2, pp.369-392, 1984.4.

3) 島田友典・渡邊康玄・横山洋 : 十勝川千代田実験水路にお ける横断堤を用いた正面越流破堤実験, 寒地土木研究所 月報，No670, 2009.3.

4) 島田友典・渡邊康玄・横山洋·辻珠希 : 千代田実験水路横 断堤における越水破堤の拡幅過程, 河川技術論文集, 第 15 巻, pp.333-338, 2009.

5) 平成 19 年度施行, 千代田実験水路外地質調查業務報告書.

6）伊藤幸義・島田友典・横山洋・坂野章・茂木映治 : 模型実 験による汇濫域を含む越流破堤メカニズム検討, 河川技術 論文集，第 16 巻, pp.371-376, 2010 .

7) 辻本哲郎・北村忠紀・岸本雅彦: 砂質堤防の破堤拡大過程 のシミュレーションと破堤水理,河川技術論文集，第 8 巻， pp.31-36, 2002 .

8）市原哲也・島田友典・横山洋 : 千代田実験水路における基 礎的な水理特性-千代田実験水路の河床形態と土砂移動に ついて, 北海道開発局技術研究発表会, 技-05, 2009.

9）禅野浩貴·岩崎理樹・清水康行・木村一郎: 越流破堤現象 に対する平面二次元モデルの適用性の検討, 土木学会北 海道支部論文報告集，第 66 号 B-8，2009.

（2010.9.30 受付） 